Thorax (1976), 31, 660.

\title{
Sarcoidosis of the upper respiratory tract and its association with lupus pernio
}

\author{
E. NEVILLE, R. G.S. MILLS ${ }^{1}, D . K$. J A S H, \\ D. M. Ma C K I N ON, L.S. CARSTAIR S, \\ and D. GER A I N T J M ES \\ Departments of Medicine and ENT Surgery, Royal Northern Hospital, London N7
}

\begin{abstract}
Neville, E., Mills, R. G. S., Jash, D. K., MacKinmon, D. M., Carstairs, L. S., and James, D. G. (1976). Thorax, 31, 660-664. Sarcoidosis of the upper respiratory tract and its association with lupus pernio. In a series of 34 patients with sarcoidosis affecting the upper respiratory tract and nose, 26 had lupus pernio (LP) and 17 had sarcoidosis of the upper respiratory tract (SURT). In nine patients these features coexisted. A patient presenting with SURT carried a 50\% risk of developing LP although one feature could be present without the other. Both were disorders of women of the child-bearing years of life. SURT, like LP, was an indicator of chronic fibrotic sarcoidosis, developing insidiously and progressing indolently over the years. It was complicated by ulceration, septal perforation, and LP. Three patients had nasal septal perforations, in two instances following submucous resection. This operation is contraindicated in patients with active sarcoidosis, particularly when granulomas are found on nasal biopsy. The KveimSiltzbach skin test was positive in all patients with SURT, making it invaluable in the differential diagnosis of granuloma of the nasal cavity.
\end{abstract}

Lupus pernio (LP) is a chronic, persistent, violaceous skin lesion with a predilection for nose, cheeks, and ears. Since this is a cosmetic disaster, its early recognition and possible prevention are important. Lupus pernio is a manifestation of chronic multisystem sarcoidosis (James, 1959). Sarcoidosis may also affect the mucosa of the upper respiratory tract including the nasopharynx (Boeck, 1905; Schaumann, 1936) and the larynx (Ulrich, 1918) as well as the nasal bone (Curtis, 1964). Lupus pernio is known to be associated with sarcoidosis of the mucosa of the nasal cavity (Kreibich and Kraus, 1908), but the nature of this association has hitherto been unclear. Our study is designed to clarify this relationship.

\section{MATERIAL AND METHODS}

We report a series of 34 patients with clinical and histological evidence of sarcoidosis in whom at some time in the course of the disease there was LP in 26 and sarcoidosis of the upper respiratory tract (SURT) in 17; in nine patients these features coexisted. In all 17 patients with mucosal

'Present address: Royal Free Hospital, London NW3 involvement the nasal mucosa was involved, the pharynx and larynx being affected less often.

Thirty-two of these patients were discoverect in the course of a survey of patients attending our special clinic at the Royal Northern Hospital.

In order to assess the frequency of involve ment of the upper respiratory tract, exhaustive examination of the upper respiratory tract was carried out by the same ear, nose, and throap surgeon on 100 successive patients attending the clinic. When necessary this clinical examination was supplemented by special radiographs, fibre $\rightarrow$ oscopy, audiometry, and also examination an biopsy under general anaesthesia.

Other investigations included chest radiograph of radiography of the hands, feet, and nasal bone Kveim-Siltzbach skin test, tuberculin test, and serum and urine calcium levels. Normal serume calcium values were up to $10.5 \mathrm{mg} / \mathrm{dl}(2.6 \mathrm{mmol} / 1)$ and 24-hour urine calcium up to $300 \mathrm{mg}$ (7.5 mmol).

Follow-up has been from three to 43 years with a mean of 11 years. The patients with SURT alone have a mean period of follow-up of five years. 


\section{RESULTS}

SEX, AGE AND RACE Twenty-nine of the $34(85 \%)$ patients were female. Patients with mucosal disease presented predominantly in the third decade whereas LP presented most often in the fourth and fifth (Figure). Twenty-five (74\%) of the patients were Caucasian, eight $(23 \%)$ Negro, and one was a Kenyan Asian (Table I).

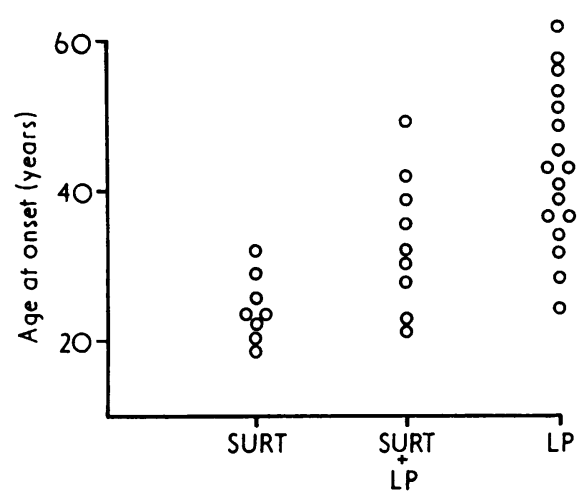

FIGURE Age of onset of patients with sarcoidosis of the upper respiratory tract (SURT), lupus pernio $(L P)$, and both of these features.

\section{T A B L E I}

CLINICAL FEATURES OF 34 PATIENTS WITH SARCOIDOSIS OF THE NOSE DISTINGUISHING LUPUS PERNIO (LP) ALONE, LP ACCOMPANIED BY SARCOIDOSIS OF THE UPPER RESPIRATORY TRACT (SURT), AND SURT ALONE

\begin{tabular}{|c|c|c|c|c|c|c|c|c|}
\hline \multirow[b]{2}{*}{ Features } & \multicolumn{2}{|c|}{ LP } & \multicolumn{2}{|c|}{$\begin{array}{l}\text { LP and } \\
\text { SURT }\end{array}$} & \multicolumn{2}{|c|}{ SURT } & \multicolumn{2}{|c|}{ Overall } \\
\hline & $\begin{array}{l}\text { No. } \\
\text { (17) }\end{array}$ & $(100)$ & $\begin{array}{l}\text { No. } \\
\text { (9) }\end{array}$ & $(100)$ & $\begin{array}{l}\text { No. } \\
\text { (8) }\end{array}$ & $(\%)$ & $\begin{array}{l}\text { No. } \\
\text { (34) }\end{array}$ & $(100)$ \\
\hline $\begin{array}{l}\text { Female } \\
\text { Age } 11-30 \\
31-40 \\
\text { over } 40 \\
\text { White } \\
\text { Negro } \\
\text { Indian }\end{array}$ & $\begin{array}{r}15 \\
2 \\
5 \\
10 \\
14 \\
3 \\
-\end{array}$ & $\begin{array}{l}88 \\
12 \\
30 \\
58 \\
82 \\
18 \\
\end{array}$ & $\begin{array}{l}8 \\
5 \\
2 \\
2 \\
6 \\
3 \\
-\end{array}$ & $\begin{array}{l}89 \\
56 \\
22 \\
22 \\
67 \\
33 \\
-\end{array}$ & $\begin{array}{l}6 \\
7 \\
1 \\
5 \\
2 \\
1\end{array}$ & $\begin{array}{l}75 \\
88 \\
12 \\
63 \\
25 \\
12\end{array}$ & $\begin{array}{r}29 \\
14 \\
8 \\
12 \\
25 \\
8 \\
1\end{array}$ & $\begin{array}{r}85 \\
41 \\
24 \\
35 \\
74 \\
23 \\
3\end{array}$ \\
\hline $\begin{array}{l}\text { Other lesions } \\
\text { Intrathoracic } \\
\text { Skin }\end{array}$ & $\begin{array}{l}13 \\
11\end{array}$ & $\begin{array}{l}76 \\
66\end{array}$ & $\begin{array}{l}7 \\
6\end{array}$ & $\begin{array}{l}78 \\
67\end{array}$ & $\begin{array}{l}8 \\
3\end{array}$ & $\begin{array}{r}100 \\
38\end{array}$ & $\begin{array}{l}28 \\
20\end{array}$ & $\begin{array}{l}82 \\
59\end{array}$ \\
\hline $\begin{array}{l}\text { Bone } \\
\text { Oymphadenopathy } \\
\text { Ocular }\end{array}$ & $\begin{array}{l}6 \\
4 \\
6\end{array}$ & $\begin{array}{l}35 \\
23 \\
35\end{array}$ & $\frac{3}{1}$ & $\frac{33}{11}$ & $\begin{array}{r}2 \\
4 \\
-\end{array}$ & $\begin{array}{l}24 \\
50 \\
-\end{array}$ & $\begin{array}{r}11 \\
8 \\
7\end{array}$ & $\begin{array}{l}32 \\
23 \\
20\end{array}$ \\
\hline
\end{tabular}

LUPUS PERNIO In all 26 patients, the skin of the nose was affected, the degree of affliction ranging from small button-like lesions or a few nodules mainly on the tip of the nose to an exuberant reaction involving all the skin of the nose and spreading across both cheeks. There were often outlying nodules or plaques on the cheeks, an eyelid was involved twice, and the pinnae of both ears twice. One patient with undoubted LP of the ear was omitted from this series since there was no involvement of the skin of the nose during our period of observation.

\section{SARCOIDOSIS OF THE UPPER RESPIRATORY TRACT}

Nasal mucosa The nasal mucosa was affected in all 17 patients with SURT. This produced obstruction, crusting, and discharge in varying degree. The septum and inferior turbinates were most commonly involved though sometimes the lesions were more widespread. The mucosa was usually erythematous and granular, and polypoid hypertrophy caused nasal obstruction; this was aggravated when stagnation and crusting led to suppuration, discharge, and rarely epistaxis.

Six of the 100 sarcoidosis patients studied consecutively had SURT, in three instances accompanying LP.

Laryngeal and pharyngeal mucosa Sarcoidosis of the larynx was observed in five patients, all of whom had both nasal cavity involvement and LP, and all of whom complained of hoarseness. The laryngeal lesions consisted of either supraor sub-glottic granulomas. No cordal lesions were seen. One patient had LP and a nasal discharge; examination revealed the combination of atrophic rhinitis, pharyngitis, and laryngitis. Another had nasal mucosal involvement but not LP at the time of appearance of the laryngeal lesion; progression to LP occurred two years later. In addition to hoarseness, this patient had marked laryngeal obstruction with stridor. Florid supraand sub-glottic granulomas were present. The obstruction was relieved by $80 \mathrm{mg}$ oral prednisolone daily, making tracheostomy unnecessary.

SURT ASSOCIATED WITH LP Of the 17 patients with mucosal sarcoidosis involving the nasal cavity, 12 $(70 \%)$ presented with nasal symptoms. Within two years, six $(50 \%)$ patients developed disfiguring LP. Only one patient presented with LP and two years later, when nasal mucosal biopsy was performed, was found to have SURT. Two patients simultaneously developed SURT and LP. 
SURT AND SEPTAL PERFORATION Nasal septal perforation was observed in three patients; two had undergone submucous resection to alleviate obstruction at a time when nasal sarcoidosis remained unrecognized. Septal perforation complicated surgery in both, and one also developed palatal perforation. Both also progressed to LP. In these two, nasal obstruction was the only presenting symptom of the systemic disorder. No other patient had a submucous resection.

NASAL BONE SARCOIDOSIS Osteolytic nasal bone lesions were found in three of nine patients with LP and in one of four patients with SURT alone. The appearance was that of osteoporosis with punched-out lesions, as previously described (Curtis, 1964).

MULTISYSTEM INVOLVEMENT WITH SARCOIDOSIS Other manifestations of sarcoidosis in the 34 patients included involvement of lung, skin, bone, lymph nodes, and eye (Table I). Sarcoidosis had an equally insidious onset and chronic protracted course in all systems.

Intrathoracic sarcoidosis Intrathoracic involvement occurred in $28(82 \%)$ patients (Table II). Bilateral hilar lymphadenopathy (BHL) was invariable when SURT occurred independently of LP; and chest resolution was evident in but two of eight $(25 \%)$ patients. In patients with LP and pulmonary sarcoidosis, likewise, only five of 20 $(25 \%)$ had eventual resolution of their chest radiographs. One of the eight patients presenting with BHL and SURT also developed pulmonary infiltration, and three of 20 patients with intrathoracic sarcoidosis and LP had progressively worsening chest radiographs.

\section{T A B L E I I}

CHEST RADIOGRAPHIC CHANGES IN 34 PATIENTS WITH LUPUS PERNIO (LP) AND SARCOIDOSIS OF THE UPPER RESPIRATORY TRACT (SURT)

\begin{tabular}{|c|c|c|c|c|c|c|c|c|}
\hline \multirow[b]{2}{*}{ Radiographic Stage } & \multicolumn{2}{|c|}{$\mathbf{L P}$} & \multicolumn{2}{|c|}{$\begin{array}{l}\text { LP and } \\
\text { SURT }\end{array}$} & \multicolumn{2}{|c|}{ SURT } & \multicolumn{2}{|c|}{ Overall } \\
\hline & $\begin{array}{l}\text { No. } \\
\text { (17) }\end{array}$ & $\begin{array}{c}\% \\
(100)\end{array}$ & $\begin{array}{l}\text { No. } \\
\text { (9) }\end{array}$ & $\begin{array}{c}\% \\
(100)\end{array}$ & $\begin{array}{l}\text { No. } \\
\text { (8) }\end{array}$ & $\begin{array}{c}\% \\
(100)\end{array}$ & $\begin{array}{l}\text { No. } \\
\text { (34) }\end{array}$ & $(100)$ \\
\hline $\begin{array}{l}0 \\
1 \\
2 \\
3\end{array}$ & $\begin{array}{l}4 \\
6 \\
5 \\
2\end{array}$ & $\begin{array}{l}23 \\
35 \\
30 \\
12\end{array}$ & $\begin{array}{l}2 \\
2 \\
4 \\
1\end{array}$ & $\begin{array}{l}22 \\
22 \\
44 \\
11\end{array}$ & $\overline{\mathbf{8}}$ & $\underline{100}$ & $\begin{array}{r}6 \\
16 \\
9 \\
3\end{array}$ & $\begin{array}{r}18 \\
47 \\
26 \\
9\end{array}$ \\
\hline Total & 13 & 77 & 7 & 78 & 8 & 100 & 28 & 82 \\
\hline
\end{tabular}

Other skin lesions Skin sarcoidosis other thano LP was also evident in three-fifths of all patientso (Table I), comprising plaques, subcutaneous nodules, and two patients each with a singled purple-red toe. There were no patients witho erythema nodosum.

Bone sarcoidosis Bone cysts of hands and feet $\vec{\circ}$ were noted in $11(32 \%)$ patients, predominantly $\vec{\omega}$ in the group with LP; they caused pain, stiffness and swelling which necessitated oral steroids anc $\vec{x}$ chloroquine.

Ocular involvement Chronic relapsing anterioros uveitis was noted in seven $(20 \%)$ patients, onces accompanied by glaucoma and twice progressing to secondary cataract formation.

Miscellaneous tissue involvement Peripherab lymphadenopathy was noted in eight $(23 \%$ ) patients. Hepatomegaly was found in four patients with LP, but splenomegaly was not observed Unilateral facial palsy of lower motor neurone type occurred in three patients with LP, but there were no other central nervous system signs. Two patients with SURT had lacrimal gland enlargement, one of whom developed L.P, but parotic swelling was not seen.

\section{INVESTIGATIONS}

Kveim-Siltzbach skin test The Kveim-Siltzbach skin test was positive in all 14 patients in the series with mucosal involvement (with and with out LP) but negative in six of 10 patients witlo LP lacking mucosal involvement (Table III).

Tuberculin test The tuberculin test was negative in 12 of $14(86 \%)$ patients with SURT, and in four of seven $(57 \%)$ patients with LP alone.

Calcium metabolism Hypercalcaemia was noted in two of $23(7 \%)$ patients, and hypercalciuria in four of $14(28 \%)$ patients; there was no obvious

T A B L E I I I

SKIN TESTS IN 34 PATIENTS WITH LUPUS PERNIO (LPS AND SARCOIDOSIS OF THE UPPER RESPIRATORY TRACTO

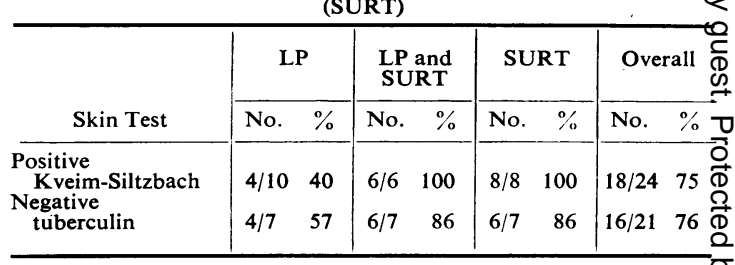


relationship between LP, SURT, and abnormal calcium metabolism.

\section{DISCUSSION}

A patient presenting with sarcoidosis of the upper respiratory tract (SURT) has a $50 \%$ risk of developing lupus pernio (LP), although one feature may be present without the other. SURT occurred in $6 \%$ of patients with generalized sarcoidosis; it has previously been reported (Cowdell, 1954; James, 1956; Israel and Sones, 1958) in from $0.6 \%$ to $10 \%$ of such patients. Whereas sarcoidosis has no special sex predilection (Siltzbach et al., 1974), SURT and LP are nearly six times commoner in women. The age of onset and race of the patients were, however, no different from those of sarcoidosis patients the world over, though SURT presented in a younger age group than LP.

SURT, like LP, is an indicator of chronic fibrotic sarcoidosis. It developed insidiously and progressed indolently over the years. This confirmed a previous report in which only three of 14 patients with SURT achieved resolution (McKelvie et al., 1968). It is complicated by ulceration, septal perforation, and LP. It is associated with other chronic lesions-intrathoracic, skin, bone and peripheral lymphadenopathy. Intrathoracic involvement shows little tendency to resolution, only $25 \%$ of patients achieving a normal chest radiograph compared to $51 \%$ in a large worldwide series (Siltzbach et al., 1974). The skin lesions consist of chronic plaques and subcutaneous nodules while bone lesions are well recognized as a long-standing complication of sarcoidosis (Sharma et al., 1971).

SURT may be complicated by nasal septal or palatal perforations so submucous resection is not recommended if the original biopsy reveals sarcoid tissue. We confirm septal or palatal perforation noted in three earlier reports (Allison and Mikell, 1932; Barmwater, 1936; Lindsay and Perlman, 1951). In two of these three patients, submucous resection was also an aetiological factor.

The differential diagnosis of a sarcoid granuloma discovered on biopsy of the upper respiratory tract includes sarcoidosis, tuberculosis, Wegener's granulomatosis, and leprosy (Black, 1966). It is clearly important to make a precise diagnosis as early as possible for the course, prognosis, and treatment vary with each disease. In this respect the Kveim-Siltzbach skin test is most useful.
It is of interest that the Kveim-Siltzbach skin test was positive in all cases of SURT but in less than half of those with LP alone. It has previously been reported that the Kveim-Siltzbach skin test is less likely to be positive in patients who have had sarcoidosis for more than two years (James, Sharma, and Bradstreet, 1967). Our KveimSiltzbach test results underline the observation that those patients with LP alone had a later stage of sarcoidosis and had had it longer than those with SURT alone.

The Clinical Research Unit of the former North-West Metropolitan Regional Hospital Board gave generous financial support. We are grateful to the Camden and Islington Area Health Authority for continuing this support. We would like to thank all those who have referred patients to the Sarcoidosis Clinic at the Royal Northern Hospital.

\section{REFERENCES}

Allison, J. R. and Mikell, P. V. (1932). Sarcoid associated with tuberculosis of the larynx. Archives of Dermatology and Syphilology, 25, 334.

Barmwater, K. (1936). Ưber Boecks Sarkoid auf den Schleimhäuten. Hals-Nasen-und Ohrenartz, I Teil, 27, 259.

Black, J. M. (1966). Sarcoidosis of the nose. Journal of Laryngology and Otology, 80, 1065.

Boeck, C. (1905). Fortgesetzte Untersuchungen über das multiple benigne Sarkoid. Archiv für Dermatologie und Syphilis, 73, 301.

Cowdell, R. H. (1954). Sarcoidosis with special reference to diagnosis and prognosis. Quarterly Journal of Medicine, 23, 29.

Curtis, G. T. (1964). Sarcoidosis of the nasal bones. British Journal of Radiology, 37, 68.

Israel, H. L. and Sones, M. (1958). Sarcoidosis: clinical observations in one hundred and sixty cases. Archives of Internal Medicine, 102, 766.

James, D. G. (1956). Diagnosis and treatment of sarcoidosis. British Medical Journal, 2, 900.

James, D. G. (1959). Dermatological aspects of sarcoidosis. Quarterly Journal of Medicine, 28, 109.

James, D. G., Sharma, O. P., and Bradstreet, P. (1967). The Kveim-Siltzbach test. Lancet, 2, 1274.

Kreibich, C. and Kraus, A. (1908). Beiträge zur Kenntniss des Boeckschen benignen Miliarlupoid. Archiv für Dermatologie und Syphilis, 92, 173.

Lindsay, J. R. and Perlman, H. B. (1951). Sarcoidosis of the upper respiratory tract. Annals of Otology, Rhinology and Laryngology, 60, 549. 
McKelvie, P., Gresson, C., Pokhrel, R. P., and Jackson, P. (1968). Sarcoidosis of the upper air passages. British Journal of Diseases of the Chest, 62, 200.

Schaumann, J. (1936). Lymphogranulomatosis benigna in the light of prolonged clinical observations and autopsy findings. British Journal of Dermatology, 48, 399.

Sharma, D. P., Bailey, A. R., Carstairs, L. S., and James, D. G. (1971). Bone involvement in sarcoidosis. In Proceedings of the Vth International Conference on Sarcoidosis, edited by L. Levinsky and F. Machoida, p. 594. University Karlova, Prague.
Siltzbach, L. E., James, D. G., Neville, E., Turiaf, J., Battesti, J. P., Sharma, O. P., Hosoda, Y., Mikami, R., and Odaka, M. (1974). Course and prognosis of sarcoidosis around the world. American Journal of Medicine, 57, 847.

Ulrich, K. (1918). Die Schleimhautveränderungen der oberen Luftwege beim Boeck'schen Sarkoid und ihre Stellung zum Lupus pernio. Archiv für? Laryngologie und Rhinologie, 31, 506.

Requests for reprints to: Dr. D. Geraint James, Royal Northern Hospital, London N7. 